\title{
URGENCY OF SQ (SPIRITUAL QUOTIENT) IN SUPPORTING ISLAMIC EDUCATION SUCCESS
}

\author{
Bahrul Ulum. ${ }^{1}$ Mahsun Jayadi ${ }^{2}$ \\ bahrululumahmad95@gmail.com.1mahsun_umsby@gmail.com
}

\begin{abstract}
Spiritual Quotient (SQ), now being warmly discussed on various occasions. Various perspectives and approaches of it are being developed from science, psychology and religion. This study aims to explore what the meaning of SQ is, how successful Islamic education is, and how urgency of SQ in supporting the success of Islamic education is. This type of research includes literature study with hermeneutic approach, and the source data are books about education, psychology, aspects of intelligence. Data collection technique used is documentation technique and is analyzed by deductive and inductive methods. The findings of this study can be summarized: firstly, spiritual quotient is the human ability to solve problems that originate in empirical facts and conscience; secondly, Islamic education is said to succeed when it has been able to develop the cognitive, affective and psychomotor aspects of the students. And more importantly, the development of the three domains is a change that can bridge the individual with society and individuals with his Kholiq (creator); thirdly, SQ is very important in realizing the success of Islamic education because SQ can help to improve the ability of students in developing their spheres.
\end{abstract}

Keywords: SQ meaning, Islamic education success, SQ urgency

\section{A. Introduction}

THE WORLD HAS BEEN STRUCK WITH INTELLECTUAL INTELLIGENCE, INTELLIGENCE QUOTIENT (IQ). THERE IS HARDLY ANY TALK OF COMPARING THE QUALITY BETWEEN US, EXCEPT WITH THE IQ GAUGE. WE ALSO FLOCKED TO THE IQ TEST TO KNOW THE EXTENT OF OUR POTENTIAL AND ABILITY. THEN IQ BECOMES A PRIDE WHEN THE VALUE IS HIGH. ARMED WITH A HIGH IQ, WE FEEL THAT WE MUST BE SUCCESSFUL PEOPLE.

IN THE FIELD, WHEN MANY FACTS APPEAR ARE NOT IN ACCORDANCE WITH THE IQ BENCHMARKS, WE ALSO BECOME UNFAMILIAR. HOW CAN THOSE WITH LOWER IQ BE MORE SUCCESSFUL THAN THOSE WITH HIGHER IQ? WHAT HAPPENS? AT THAT TIME, A NEW THEORY EMERGED, A NEW BENCHMARK. WE 
ALSO KNOW THE NEW INTELLIGENCE, THE EMOTIONAL QUOTIENT (EQ). THEN IT IS PROVEN FROM VARIOUS RESEARCH RESULTS, EMOTIONAL INTELLIGENCE HAS A MORE IMPORTANT ROLE THAN INTELLECTUAL INTELLIGENCE. BRAIN INTELLIGENCE THEN IS A MINIMUM REQUIREMENT TO ACHIEVE SUCCESS, AND THEN EMOTIONAL INTELLIGENCE ACTUALLY LEADS TO THE PEAK OF ACHIEVEMENT.

FINALLY, PEOPLE WHO HAVE A GOOD IQ AS WELL AS A GOOD EQ CAN REACH THE PEAK OF ACHIEVEMENT. BUT, IN FACT, THE PEAK OF ACHIEVEMENT REACHED, IS ONLY THE TOPS OF ACHIEVEMENT HILL, NOT THE TOP OF THE ACHIEVEMENT MOUNTAIN. AS A RESULT, IN THE MIDST OF THEIR SUCCESS, THE OWNERS OF THE TWO EXISTING INTELLIGENCES HAVE COLLAPSED ON THEMSELVES. THEIR SOULS BECOMES EMPTY. THEIR DESIRES WANT TO GET TO THE TOP OF THE ACHIEVEMENT MOUNTAIN, BUT THEIR PROVISION IS ONLY ABLE TO BRING TO THE TOP OF THE ACHIEVEMENT HILL. THIS CREATES AN UPHEAVAL WITHIN THEM THAT CAN LEAD TO FRUSTRATION. AS A RESULT, IT IS NOT THE PART THEYE GET BUT THE ANXIETY THAT PLAGUES THEM. NOT SATISFACTION, BUT THIRST WITHOUT LIMIT. IT IS SAID IN A SYI'IR (POEM): THE WORLD IS LIKE SEA WATER / DRUNK INCREASINGLY THIRSTY. BEING POWERLESS GETS THEIR LUSTS; THE HILLTOP OF HIS ACHIEVEMENT IS ENTIRELY RELATIVE. IT IS USELESS. ${ }^{I}$

SPIRITUAL INTELLIGENCE WE KNOW BY THE NAME OF SQ NOW BEING WARMLY DISCUSSED IN VARIOUS OCCASIONS. VARIOUS PERSPECTIVES AND APPROACHES ARE BEING DEVELOPED FROM SCIENCE, PSYCHOLOGY AND RELIGION.

SPIRITUAL INTELLIGENCE (SQ), WHICH IS THE LATEST SCIENTIFIC FINDING, WAS FIRST PROPOSED BY DANAH ZOHARI AND LAN MARSHALL, RESPECTIVELY FROM HARVARD UNIVERSITY

1 Suharto, Dedi AK, Qur'anic Quotient: Bagaimana Membangun Kecerdasan Menurut Al-Qur'an (Jakarta : Yayasan Ukhuwa, 2003), 2. 
AND OXFORD UNIVERSITY THROUGH A VERY COMPREHENSIVE RESEARCH. SCIENTIFIC PROOFS OF SPIRITUAL INTELLIGENCE PRESENTED BY ZOHAR AND MARSHALL IN SQ (SPIRITUAL QUOTIENT) THE ULTIMATE INTELLIGENCE, TWO OF WHICH ARE: FIRST, RESEARCH PSYCHOLOGIST / NEUROLOGIST, MICHAEL PERSINGER IN THE EARLY 1990S, AND MORE RECENTLY AGAIN IN 1997 BY NEUROLOGIST, V. S. RAMACHAN DRAN AND HIS TEAM FROM CALIFORNIA DISCOVERED AN EXISTENCE OF A GOD-SPOT IN THE HUMAN BRAIN. IT'S BUILT-IN AS A SPIRITUAL CENTER (SPIRITUAL CENTER) LOCATED BETWEEN THE NETWORK OF REQUIREMENTS AND THE BRAIN.

THEN, THE SECOND PROOF IS AUSTRIAN NEUROLOGIST RESEARCH. WOLF SINGER IN THE 1990S OVER THE BINDING PROBLEM SHOWED THERE IS A NERVOUS PROCESS IN THE HUMAN BRAIN THAT IS CONCENTRATED ON THE EFFORT THAT UNIFIES AND GIVES MEANING IN OUR LIFE EXPERIENCES. THE NEURAL NETWORK THAT LITERALLY “BINDS”. THE DEEPEST HUMAN NATURE IS IN THESE GOT-SPOTS. ${ }^{2}$

BUT THE WESTERN SQ OR SPIRITUAL INTELLIGENCE HAS NOT YET OR EVEN NOT REACHED THE DIVINITY. THE DISCUSSION IS MERELY ONLY LIMITED TO THE LEVEL OF BIOLOGY OR PSYCHOLOGY, BUT NOT TRANSCENDENTAL. AS A RESULT, WE STILL FEEL THE “DEADLOCK”. 3

WE USE SQ TO ACHIEVE MORE COMPLETE SELFDEVELOPMENT BECAUSE WE HAVE POTENTIAL FOR IT, WE USE SQ TO BE CREATIVE, WE PRESENT IT WHEN WE WANT TO BE FLEXIBLE, INSIGHTFUL, OR SPONTANEOUSLY CREATIVE.

2 Danah Zohar, dan Lan Marshall, $S Q$ : Memanfaatkan Kecerdasan Spiritual dalam Berpikir Integralistik dan Holistik untuk Memaknai Kehidupan (Bandung : Mizan, 2002), 10.

3 Ari Ginanjar Agustian, Emotional Spiritual Quotient (Jakarta : Arga, 2001), i-v. 
THEREFORE, THE FORMATION OF HUMAN BELIEF AND PIETY TO ALLAH SWT BECOME THE FIRST AND MAIN BENCHMARK IN THE MANAGEMENT OF EDUCATION IN INDONESIA. SCHOOL IS A PLACE FOR STUDENTS TO LEARN TO SOCIAL, IN ORDER TO FUNCTION AND ABLE ACTUALIZE THEMSELVES AS A SERVANT OF GOD AND CALIPH ON EARTH. SCHOOL AIMS TO FORM NOT ONLY A FAITH, KNOWLEDGEABLE, AND SKILLED MAN BUT ALSO A MAN WITH FULL OF CHARITY SPIRIT, SO AS TO CREATE A RESPECTABLE SOCIETY IN THE WORLD AND SURVIVED IN THE HEREAFTER. SCHOOL ALSO AIMS TO HELP THE FORMATION OF CREATIVE AND RESPONSIBLE HUMAN BEINGS TO GOD.

THE NUANCES OF THE SPIRITUAL GOALS OF INDONESIA'S EDUCATION AWAKEN US TO THE IMPORTANCE OF SPIRITUAL CONCEPTS TO BE FORMULATED AND IMPLEMENTED IN OUR EDUCATION SYSTEM. WITH ADEQUATE POSSESSION OF SPIRITUAL intelligence, THE STUDENT WILL BE ABLE TO CONTROL HIMSELF AND RETURN ALL THE EVENTS HE EXPERIENCED TO THE HOLDER OF THE HIGHEST VALUE AUTHORITY, NAMELY ALLAH SWT. THE PURPOSE OF THE EDUCATION SYSTEM IN INDONESIA TO FORM A HUMAN FAITHFUL AND DEVOTED, OF COURSE, NEED TO INVOLVE THREE MAIN ELEMENTS OF EDUCATION, NAMELY PARENTS, SCHOOLS AND COMMUNITIES IN DEVELOPING STUDENT POTENTIAL. ${ }^{4}$

Based on the above description, the author is motivated to conduct a study with the title: "Urgency of SQ (Spiritual Quotient) in supporting the success of Islamic education".

\section{B. Research Method}

THIS RESEARCH IS LIBRARY RESEARCH (LITERATURE RESEARCH), WITH HERMENEUTIC APPROACH USED TO ANALYZE

4 Suharsono, Mencetak Anak Cerdas (Depok : Inisiasi Press, 2004), viii. 
QUALITATIVE DATA. HERMENEUTICS AS A METHOD OF UNDERSTANDING - AS EMILIO BETTI POINTS OUT - IS AN INTERPRETIVE ACTIVITY OF A MEANINGFUL FORM OBJECT WITH THE AIM OF GENERATING THE POSSIBILITY OF AN OBJECTIVE UNDERSTANDING. ${ }^{5}$

AS FOR THE TYPE OF LITERARY RESEARCH THAT THE AUTHOR TAKES IS LITERATURE STUDIES THAT REQUIRE THEORETICAL SIGNIFICANCE TEST. THIS STUDY HAS THE UTILITY TO CONSTRUCT THEORETICAL CONCEPTS THAT IN TIME REQUIRE THE TEST OF MEANINGFULNESS OF CONCEPTS IN THE FIELD. ${ }^{6}$ AS A THEORETICAL STUDY OF A DISCIPLINE, THE AUTHOR TRIES TO APPLY THE THEORY TO THE PROBLEMS CONTAINED IN THIS STUDY.

IN THIS STUDY, DATA COLLECTION IS DONE DOCUMENTARY METHOD THAT IS LOOKING FOR DATA ABOUT MATTERS RELATING TO THE DISCUSSION, IN THE FORM OF NOTES, TRANSCRIPTS, BOOKS, NEWSPAPERS, MAGAZINES AND OTHERS. THIS TECHNIQUE IS USEFUL AS A PROOF OF A TEST BECAUSE IT CAN BE USED TO TEST, INTERPRET, EVEN PREDICT ITS NATURE AND CONTEXTUAL PROPERTIES IN ACCORDANCE WITH THE AUTHOR'S SELECTION. ${ }^{7}$

\section{Research Finding and Discussion}

\section{Meaning and Urgency of Spiritual Quotient (SQ)}

According to Donah Zohar", spiritual intelligence (SQ) is "kecerdasan yang bertumpu pada bagian dalam diri kita yang berhubungan dengan kearifan di luar ego,

5 E. Sumaryono, Hermeneutik : Sebuah metode filsafat (Yogyakarta : Kanisius, 1995), 31.

6 Noeng Muhajir, Metologi Penelitian Kualitatif(Yogyakarta : Rake Sarasin, 1996), 159.

7 Lexy Moeleong, Metodologi Penelitian Kualitatif (Bandung : Remaja Rosdakarya, 2002), 161. 
atau jiwa sadar." It is an inward-minded intelligence associated with wisdom beyond the ego, or the conscious soul.

In Sinetar's point of view" "Kecerdasan spiritual adalah pikiran yang mendapat inspirasi, dorongan, dan efektifitas yang terinspirasi, theisness atau penghayatan ketuhanan yang di dalamnya kita semua menjadi bagian". Spiritual intelligence is an inspired mind, encouragement, and inspired effectiveness, theism or a divine devotion in which we all belong to.

While according to Muhammad Zuhri, ${ }^{10}$ IQ is the human intelligence that humans primarily use to connect with and manage nature. The IQ of each person is influenced by the material of his brain, which is determined by genetic factors. Yet the potential of IQ is huge. While EQ is a human intelligence that is primarily, used humans to relate and cooperate with other humans. A person's EQ is influenced by the conditions within himself and his society, as the customs and traditions. The human EQ potential is greater than IQ. While SQ is the human intelligence used to "relate" to God. Everyone's SQ potential is huge, and is not limited by heredity, environment, or other material.

While in $\mathrm{ESQ}^{11}$, spiritual intelligence is the ability to give meaning for the worship of every behavior and activity through the steps and thoughts that are fitrah (original/natural character). Besides, it is including to be the whole person (hanif), and to have the pattern of thinking Tauhidi (integral) that "just because of God".

In the easy language, spiritual intelligence (SQ) is the ability of a person to know his Lord (Ma'rifatullah). By knowing God, the man will experience success in his life, not only in the world but also in the afterlife. For the reason, he will start everything in the name of God and return whatever the result to God.

8 Donah Zohar, dan Lan Marshall, $S Q$ : Memanfaatkan Kecerdasan Spiritual dalam Berpikir Integralistik dan Holistik untuk Memaknai Kehidupan (Bandung : Mizan, 2002), 8.

\section{Ibid.}

10 Ibid.

11 Ari Ginanjar Agustian, Emotional Spiritual Quotient (Jakarta : Arga, 2001), 57. 
Spiritual Intelligence (SQ) must be considered in educating children. According to Komaruddin Hidayat, ${ }^{12}$ there are at least ten guidelines that can be followed to grow and develop the spiritual intelligence for our children, namely:

First: Teach the children that God is always concerned about our lives. The practice of praying and ritual habitation will soften the feelings and educate the children spiritual. In this case it is important for parents to always set a good example in the eyes of children.

Second: Teach the children that living and life are interconnected. It is impossible for us to live alone, to provide for everything we need by our selves. This relationship is not only between human beings, but also with the natural environment, such as air, water, light, plants, animals, even bacteria that support our lives.

Third: Parents should be good listeners for their children. If the child is talking, don't cut or give lecture soon. Listen and watch or gaze enthusiasticly and simulatively so that the children will be trained to express their thoughts and emotions smoothly, orderly, and clearly. Like a well, if it is often dipped then the water will be clear.

Fourth: Teach children to use beautiful words and phrases and encourage imagination. If it is difficult, it can be expressed through good reading. Get used to buying and reading books for our children. If children are interested, it can be read repeatedly to penetrate deeper message and trace.

Fifth: Encourage children to imagine about their future and about life. Imagination will train the children to always think things that transcend the boundaries of materials and this will educate their spiritual. Imagination will also activate the right brain that tends to think holistic, intuitive and imaginative.

Sixth: Discover and celebrate the miracles that happen every day or Sunday. Do not live through routine and mechanical. Many miracles happen every day that should be given meaning, be thankful, and celebrated even in a simple way but touching the children's heart.

Seventh: Give children a space to be creative, determine program and schedule activities by themselves. Children who are too organized and dictated by the parents can

12 Ibid. 
grow into rebels or otherwise become passive, not accustomed to the initiative. Teach children to understand their choices.

Eighth: Be a positive mirror for children. Unconsciously, each of household life is an actor who is always seen and rated by others. So, be an actor or role model that is good for children. Occasionally, hold a forum to convey each impression and assessment for one another in a relaxed, comfortable, and unpressured atmosphere. In fact, each must be able to appreciate the others.

Ninth: Create occasionally a really relaxed atmosphere, relinquish all tensions and both physical and psychological fatigue. This is called relaxation through relaxation.

Tenth: Every day is special, which must be appreciated and be grateful. Take the children to thank the Lord every morning while looking at the sky, the sun, the trees. Give thanks and praise for the kindness and beauty that is always present with us without charge.

By those steps above, spiritual intelligence guides the children to always worship God and thank God at all times.

\section{Successful Islamic Education}

Naturally, Islamic education is a religious education that instills the teachings and practices of religion. ${ }^{13}$ With the hope, it can form a faithful personality and doing good deeds. Understanding Islamic education is "the process of guiding and directing the growth and development of students to become human adults in accordance with the objectives of Islamic education ${ }^{14}$. Some Islamic education experts try to formulate the essence of Islamic education in the real view of "An education system that enables one to direct his life according to Islamic teachings"15. Meanwhile, according to alGhozaly ${ }^{16}:$ it is "the process of humanizing humans from the time of its incidence to the end of his life through various sciences submitted in the form of teaching gradually,

13 Sidi Gazalba, Pengantar Sejarah Sebagai Ilmu (Jakarta : Bhratara Karya Aksara, 1981), 165.

14 HM. Arifin, Ilmu Pendidikan Islam (Jakarta : Bumi Aksara, 1993), 16.

15 Muhaimin, Paradigma Pendidikan Islam (Bandung : Yayasan Nuasa Cendekia, 2002), 135. 
where the process is the responsibility of parents and society toward self approach to God so that to be a perfect human". Meanwhile, according to Ahmad D. Marimba ${ }^{17}$ : "Islamic education is a physical, spiritual guidance based on Islamic religious laws leading to the formation of the ultimate personality according to Islamic measures".

From various understanding of Islamic education above, the Islamic education is the process of guidance from all aspects of human beings based on Islamic values to realize the ideal khalifah fil ardl (caliph on the earth), so as a process, Islamic education has a purpose. The purpose of Islamic education is the formation of a perfect Muslim person as a khalifah on earth, who believe and do good deeds and happy in the world and the hereafter.

In the treasury of educational thought, ulama (theologian) generally think that the ultimate goal of Islamic education is "To worship Allah" ${ }^{18 " . ~ A c c o r d i n g ~ t o ~ I m a m ~}$ Ghazali $^{19}$, the purpose of education is the formation of the plenary, both in the world and in the hereafter. According to him, the man can achieve perfection if he wants to seek knowledge and then practice fadilah (virtue) through science learned. This fadilah can then bring him to be close to God and ultimately make him happy in the world and the hereafter. Meanwhile, the purpose of education in Islam is to form a human character ${ }^{20}$, i.e.:
a. Islamic personality
b. Mastering Islamic tsaqofah (ideology)
c. Mastering adequate life sciences (science of technology and expertise)

16 Abidin Ibnu Rusn, Pemikiran Al-Ghozali Tentang Pendidikan (Yogyakarta : Pustaka Pelajar, 1998), 56.

17 Nur Unbiyati, Ilmu Pendidikan Islam (Bandung : Pustaka Setia, 1998), 9.

18 Muhaimin, Paradigma, 48.

19 Nur Unbiyati, Ilmu, 34.

20 Muhammad Islam Yusanto, Menggagas Pendidikan Islam (Jakarta : Al-Azhar Press, 2004), 52. 
Talking about the purpose of education is closely related to the success of Islamic education, because a success is achieved through a predetermined goal where the educational goal according to al-Ghozali ${ }^{21}$ is "Shaping a righteous man." That is a perfect Muslim or a believer or a devout man or a man who worships Allah SWT. According to Ahmad Tafsir, the perfect human criterion is ${ }^{22}$ :

a.Powerful body

b.Strong

c.Skilled

d.Able to solve problems appropriately and quickly

e.Able to solve scientific and philosophical problems

f.Having and developing science

g.Having and developing philosophy.

h.Carrying out Allah's commands and stay away from his prohibitions voluntarily i.Having a heart connected to the unseen nature.

From the details of the perfect human criterion we can easily say that Islamic education is said to succeed when it has achieved the ideal goal. However, here it is necessary to describe the criteria of educational success in general, i.e. ${ }^{23}$ :

a.Education is a learning process that can produce the expected behavior.

b.Education helps the process to take place effectively and efficiently.

c.The result of education in the form of behavior is measurable and evaluated.

d.Measurement and evaluation are necessary to improve successful educational efforts.

The manifestation of a result usually appears in the habit of skill, observation, associative thinking and memory, thinking and being rational, inhibition (resistant response), appreciation (value consideration of something) and affective behavior of learners ${ }^{24}$. And according to Zakiyah Darajat, the study success of religion is reflected in the ability of the students to enjoy and realize the truth of religious teachings sincerely,

21 Abidin Ibnu Rusn, Pemikiran, 61.

22 A. Tafsir, Ilmu Pendidikan Dalam Perspektif Islam (Bandung : Remaja Rosda Karya, 1992), 50.

23 Muhaimin, Tadjab, Abdul Mujib, Pemikiran Pendidikan Islam : Kajian Filosofis Dan Kerangka DasarOperasionalnya ( Bandung : Trigenda Karya, 1993), 65. 
then make it as a system of self-worth, which in turn he is able to make this value system as a model of life in joy and sorrow.

To state that a teaching and learning process is said to be successful, every educator has their respective views according to his philosophy. However, to state the perception that we should be guided by the current curriculum, a teaching and learning process about a teaching material is declared successful if its specific instructional objectives can be achieved ${ }^{25}$ in more detail explanation as follows :

a. Absorption of teaching materials achieves both individual and group performance.

b. Behavior outlined in the purpose of teaching has been achieved by students, both individuals and groups. ${ }^{26}$

According to Tadjab, et $\mathrm{al}^{27}$ that one is said to be successful in learning when it has reached the following types of domain development:

a. Cognitive Domain

1) Knowledge

The ability to memorize is pretty good because it requires rapid repetition.

2) Comprehension

Understanding is meant as the ability to grasp meaning.

3) Application

It is the treatment of an abstraction in a specific or concrete situation. Abstraction can be an idea, theory or technical guidance.

4) Analysis

Efforts are to separate integrity into elements so that the relationship is clear.

5) Synthesis

It is attempt to unite the elements into one form with the record of incorporating new elements in unifying them.

24 Muhibbin Syah, Psikologi Belajar (Jakarta: PT Raja Grafindo Persada, 2009), 115.

25 Saiful Bahri Djamarah, Strategi Belajar Mengajar, (Jakarta : Rineka Cipta, 1997), 120.

26 Ibid., 120

27 Tadjab dkk., Dasar-dasar Kependidikan Islam (Surabaya : Karya Abditama, 1996, 247. 
6) Evaluation

It is making a decision about the value of something for a particular purpose. This evaluation is placed at the end because it involves all types of past learning outcomes.

\section{b. Affective Domain}

According to Krath Wohl et. al. ${ }^{28}$ that there are five types of affective learning outcomes:

1) Receiving

The ability to listen to, at this level, a person becomes sensitive to pay attention and receive a certain phenomenon or stimulus.

2) Responding

Ability to response, at this level, someone who likes to receive, actively select the stimulus as well as receive the response in the form of activities.

3) Valuing

The ability to judge, at this stage, one begins to make perceptions about things, phenomena or behavior out of him and perceived is the value.

4) Organization

The ability to organize values, at this stage, one begins the process of forming a certain value system, which persists from organizing values up to making private ownership value.

5) Characterization by a valve or valve complex

Having the characteristic value, at this level, values that already have a place in the hierarchy of a person's value is arranged in the system of hierarchical relationships of various values that shape his view of life, so steadfast in its application and reflection of his personality as a muslim.

c. Psychomotor Domain

1) Perception

It is using sensory organs to obtain guidance that guides motor activity.

2) Set

It is readiness to perform special activities both mentally and physically.

28 Ibid., 249 
3) Guide Response

Guided response is the first step in learning complex skills.

4) Mechanism

Performance shows the learned response has become a habit and skill.

5) Origination

It is creation of new patterns to adapt to specific situations or special problems.

In Islamic education both at the level of process and learning outcome must always be inherent with Islam. Islam must base its learning activities or become a breath for the changes that have taken place and animate the next activity. Besides learning changes must include three domains, namely cognitive, affective, psychomotor, furthermore Islam requires that the change of domain also must be a change that can bridge the individual with society and individuals with the kholiq. ${ }^{29}$

This is the embodiment of the ideals of Islamic education who want to shape the overall orientation of human life in accordance with the will of Allah SWT and consistent to the caliph-ship. As a product of Islamic education, the resulting output should reflect fully the pattern of worship orientation. According to Al-Ghozaly ${ }^{30}$, to determine the success of education is the unity between science, things and charities that are now called cognitive, affective, and psychomotor.

\section{SQ Urgence to Support Success of Islamic Education}

The discussion about SQ is indeed unique and interesting. SQ is a blend of religious knowledge and psychology. Psychology is the study of the phenomenon or the phenomenon of human behavior seen from the outward appearance alone. While SQ discussion more deeply that is the center or cause of such behavior.

According to the Qur'an, human being consists of two elements i.e. matter in the form of earth (physical) and matter in the form of divine soul (mind and soul) through a process that is not explained in detail. While human reproduction, although put forward the stages, but the stage is more soil elements.

29 Ramayulis, Ilmu, 34.

30 Abidin Ibnu Rusn, Pemikiran, 130. 
Reason serves as the thinking power contained in the human psyche, the power to gain knowledge and power to abstract the objects captured by the five senses. How high the position of reason in the teachings of Islam that is in the verses of the Qur'an and Hadits Qudsi follows in which depicted Allah SWT said to the mind which means: "For the sake of my power and majesty I do not create a nobler creature from you. For you, I pick and give, and for your sake, I send down the reward and condemn it. "

In other words, mind is the highest God's creature. Then, what the sense of connection with the human brain and mind is. The brain is the hardware of the human, the biological means to develop a framework of thinking. Mind is human software, the thinking power of the human psyche, the power which as depicted in the Qur'an to gain knowledge by observing the natural surroundings.

To find out the human brain performances, let us discuss how the brain works and what is contained in the human brain associated with this research.

\section{a. General Overview of Human Brain}

It is magic tool. That is the phrase that can be expressed to describe the brain. Why is it magic? It is because with the help of brain, the function of vision goes that our eyes can see. With the help of brain, the function of our hearing works that our ears can hear.

The brain consists of the cerebrum and cerebellum. Large brain is splitted into right hemisphere and left hemisphere. There are four lobes in it; the frontal lobe, parietal lobes, temporal lobes and the occipital lobes. The frontal lobe is the central nerve of speech and as a higher intellectual and psychic function. ${ }^{31}$ The parietal lobe is the central nerve of skin sensation, the temporal lobe is the central nerve of the hearing, and the occipital lobe is the central nerve of vision present in the forebrain.

The human midbrain that is small enough and inconspicuous to its function is to impulse between the forebrain and the back of the brain and between the forebrain and the eyes. The human rear brain consists of the cerebellum and the medulla oblongata. The cerebellum is the central nerve that regulates the balance of the body, while the medulla oblongata is an autonomic nerve regulator, ${ }^{32}$ eye blinking example, swallowing and heart rate.

31 J.G., Chusid, Neuronatomi Korelatif dan Neurologi Fungsional (Yogyakarta: Gadja Mada University Press, 1991), 24. 


\section{b. How the human brain works}

The human brain has a neuronal cell or "Neuron" of 10-100 billion, a neuron having a shape like a tree that has roots (dendrites), cell body (soma), branches (axons) and branches (axon ends).

Each neuron receives input to a dendrite that can stimulate or store it. This input travels to the body of the cell, if a certain amount of stimulus reaches the cell body at a time, it sends the action potential along the axon. The potential action is propagating like electricity until it reaches the axon. The end of the axon in turn forms a synapse (connection) to the dendrite of its neighboring neuron. A neuron has 1-10 thousand synapses that communicate directly with other neurons.

The synapses work with chemical travel, the axon end of a neuron secreting a chemical called transmitter neuron, which in turn excludes or stores the dendrites touched. That's the interaction between neurons. ${ }^{33}$ With this interaction, the brain can be said to be "Working". Then how can the brain be said to work within the scope of IQ, EQ, or SQ?

\section{1) Intelligence Quotient (IQ)}

The brain is said to work within the scope of IQ if the axon of a or a group of neurons stimulates dendrites from a or a group of neighboring neurons and a chemical electrical signal propagates along a series of neurons that work in a or a set of thoughts. Each neuron in the circuit can be set to on or off. If any one part of the neural tract is damaged or dead, the whole circuit will stop working, like a series of lamps that are strung together. "Neural tract" works according to the established program of the rules of the formal logic of neural pathways work bas the existing program. So also in the case of students, as students must learn every day. This thinking is logical without involving feelings. This is the way series thinks as a manifestation of IQ.

32 John W. Kimbal, Biologi, Part 2 (Jakarta : Erlangga, 1992), 88.

33 Donah Zohar, dan Lan Marshall, SQ : Memanfaatkan Kecerdasan Spiritual dalam Berpikir Integralistik dan Holistik untuk Memaknai Kehidupan (Bandung : Mizan, 2002), 44. 
The superiority of the series thinking (left brain) and IQ advantage is that it is accurate, precise, and reliable. ${ }^{34}$

\section{2) Emotional Quotient (EQ)}

EQ manifestation is associative thinking. It means to think with emotion and body. The structures of the brain used for associative thinking are known as neural networks. Each of these tissues contains a series of nerves up to one hundred thousand. Each nerve cell (neuron) in one cluster can be linked to thousands of other nerve groups. Unlike neural tracts that are so definite, obedient and non-creative. Each neuron in a neural network receives stimuli from other neurons simultaneously. In other words, neural networks are able to develop themselves through their interaction with experience as an example; we learn to ride instead of guide book but from experience.

Emotion grows from an area of the brain called a system of rheumatic, especially the amygdale. The amygdale, which is in Greek, means the fruit of Almond, located on each side of the brain on the side of the head. It functions like a storehouse of emotional memories. People living without the amygdale will lose their emotions. ${ }^{35}$

Joseph Ledoux (1997) neurologist at the center for neural sciences, New York University, was the first to discover the key to the amygdale in the emotional brain. His research explains how the amygdale can take control of what we do, even when the neo-cortex is still making decisions.

In summary, the workings of the amygdale are to process incoming signals and then decide what steps to take based on existing experience. The amygdale here becomes a kind of strategic post, reacting like a nerve-trigger cable by giving emergency messages (if that's the case) telegraphically to the rest of the brain.

Thus, the amygdale can make us act while the neo-cortex (the slower but fuller of the information) plans more precise action.

\section{Ibid.}

35 Femina, no.8/XXV.27 February - 5 March 2007. 
The superiority or the advantages of associative thinking (right brain) is be able to interact with experience and can continuously evolve through experience or experiment. $^{36}$

\section{3) Spiritual Quotient (SQ)}

The SQ manifestation is the united thinking so named because it unifies the various contexts and then responds them. The response form is unique, the uniqueness of which is the attempt to bring the various contexts of experience to a central point, the "Consciousness of meaning". Physically, the brain consists of a number of independent experts. Some are process of color, sound, motion and so on. But, all is united by nerve oscillations with a frequency of $35-45 \mathrm{~Hz}$ (vibrations per second). The nerve oscillations are read through the MEG screen by Wolf singer and Charles Gray in Franfurt German. The nerve oscillation eventually leads to a central point of "Consciousness" of meaning, "What's all this for?" This one point by some westerners is expressed as "The Point of God". ${ }^{37}$ This is the center of everything and this is what should underlie all the human deeds not just look for a formal value as the word of Allah in Q.S. Al-Baqarah: 148. "And for every people there is his own qiblat (Mecca) facing him. Then, compete (in doing) goodness. Wherever you are, Allah will gather you all (on the Day of Resurrection). Allah verily is all-powerful over all things."

IQ and EQ are important. SQ is also very important. SQ is an intelligence that comes from the divine ruh (spirit) blown on humans when they were in the realm of the spirit. The intelligence expressed by Ali Ibn Abi Tholib is God's highest gift given to man, who will reach the peak of actualization if he is destined as the vision of his being which God established for him.

SPIRITUAL INTELLIGENCE, SPIRITUAL INTELLIGENCE, SPIRITUAL QUOTIENT OR INTELLIGENCE SPIRITUAL (IS) IS A BLEND OF RELIGIOUS SCIENCE AND PSYCHOLOGY WHERE THE DISCUSSION OF SQ IS NOT ONLY HABLUN MINALLAH (RELATION

36 Danah Zohar, dan Lan Marshall, SQ, 49.

37 Ibid. 


\section{TO GOD) BUT ALSO HABLUN MINANNAS (RELATION AMONG \\ HUMAN BEINGS) AND NATURAL RESOURCES. SQ INDICATES US \\ THE IMPORTANCE OF SPIRITUAL INTELLIGENCE IN DEALING \\ WITH THE VARIOUS LIFE PROBLEMS WE ARE FACING. WHEN THE \\ EDUCATION AT OUR COUNTRY ONLY EMPHASIZES ON THE \\ SCIENTIFIC ASPECT ONLY, NO WONDER THEN MANY \\ INTELLECTUALS DO CORRUPTION. THE VALUE OF RELIGIOUS MORALITY PLAYS AN IMPORTANT ROLE HERE. IF THE CURRICULUM EMPHASIZES MORE ON BRAIN EXERCISE, IT SHOULD ALSO BE TRAINED IN THE SPIRITUAL FIELD.}

The success desired by Islamic education is not only limited to knowledge but also the unity between knowledge, feelings, and attitudes. Then, we should not ignore the spiritual aspect of the students in the education we provide or evaluate because the spiritual intelligence will stir up knowledge into the permanent personality and behavior. There is an important role of the SQ benefits in realizing the goals of Islamic education. A smart spiritual will be able to provide valuable access in supporting the development of the main educational aspects of cognitive, affective, and psychomotor.

In the realm of cognition, SQ is very meaningful for the ability to memorize and solve problems. In the affective domain, SQ can be a guide in determining attitudes and decisions. In psychomotor, SQ plays a role in the ability to work hard to make highlevel skills by designing a tool or creating certain works that are efficient for themselves and society in general whose aim is to expect the ridlo of Allah SWT.

\section{Conclusion}

Based on the results of research that has been described, it can be concluded that: (1) Spiritual Quotient (SQ) is the human ability to solve problems that originate in empirical facts and conscience (God spot). In more detail, the ability of SQ includes the ability ; to transcend the physical and material, to have the awareness level that culminates, to sanctify daily experience, and to use the spiritual resources to solve problems and the ability to do good things. (2) Islamic education is said to succeed when it has been able to develop the cognitive, affective and psychomotor aspects of the students. And more importantly, the development of the three domains is a change that 
can bridge the individual with society and individuals with the kholiq that is the realization of "Insan kamil" (perfect human) as abid (servant) as well as kholifah fil Ardhi. (3) SQ is very important in realizing the success of Islamic education because SQ can help improve the students ability in developing the its domain. For example, the realm of cognition, very meaningful for the ability to memorize and solve problems in the affective domain, SQ can be a guide in determining attitudes and decisions. In psychomotor, SQ plays a role in the ability to work hard to make high-level skills by designing a tool or creating certain works that are efficient for themselves and society in general whose aim is to expect the ridlo of Allah SWT.

\section{E. References}

Al-Bani, Muhammad, Anak Cerdas Dunia Akhirat, Bandung, Mujahid Press, 2004.

Al-Syaibani, Umar M. Al-Thoumy, Falsafah Pendidikan Islam, Jakarta, Bulan Bintang, 1979.

Agustian, Ari Ginanjar, Emotional Spiritual Quotient, Jakarta, Arga, 2001.

Abdurrahman, Mulyono, Pendidikan Bagi Anak Berkesulitan Belajar, Jakarta, Rineka Cipta, 1999.

Arifin, H.M., Ilmu Pendidikan Islam, Jakarta. Bumi Aksara. 1993.

Amin, Rusli, Menjadi Remaja Cerdas, Jakarta, Al-Mawardi Prima, 2003.

Bawani, Imam, Cendekiawan Dalam Perspektif Pendidikan Islam. Surabaya. Bina Ilmu. 1991.

Chusid, J.G. Neuronatomi Korelatif dan Neurologi Fungsional, Yogyakarta. Gadja Mada University Press. 1991.

Djamarah, Saiful Bahri, Strategi Belajar Mengajar, Jakarta. Rineka Cipta, 1997.

\section{FEMINA, NO.8/XXV.27 PEBRUARI - 5 MARET 2007.}

Kimbal, John. W. Biologi Jilid 2. Jakarta. Erlangga. 1992.

Langgulung, Hasan. Pendidikan dan Peradaban Islam. Jakarta. Pustaka Al Husna. 1985.

, Asas-asas Pendidikan Islam. Jakarta. Pustaka Al Husna. 1992.

Muhajir, Noeng. Metologi Penelitian Kualitatif. Yogyakarta. Rake Sarasin. 1996.

Moleong, Lexy. Metodologi Penelitian Kualitatif. Bandung. Remaja Rosdakarya. 2002.

Mudyaharjo, Redja. Filsafat Ilmu Pendidikan. Bandung. Remaja Rosdakarya. 2001.

Muhaimin dan Abdul Mujib. Pemikiran Pendidikan Islam. Bandung. Trigenda Karya. 1993.

Muhaimin. Paradigma Pendidikan Islam. Bandung. Yayasan Nuasa Cendekia. 2002.

Ramayulis. Ilmu Pendidikan Islam. Surabaya. Kalam Mulia. 1998.

Rusn, Abidin Ibnu. Pemikiran Al-Ghozali Tentang Pendidikan. Yogyakarta. Pustaka Pelajar. 1998.

Suharto, Dedi AK, Qur'anic Quotient : Bagaimana Membangun Kecerdasan Menurut Al-Qur'an, Jakarta. Yayasan Ukhuwa, 2003.

Suharsono, Mencetak Anak Cerdas, Depok, Inisiasi Press, 2004.

Sumaryono, E., Hermeneutik : Sebuah metode filsafat. Yogyakarta, Kanisius, 1995. 
Suryadi, Ace. Analisis Kebijakan Pendidikan. Bandung. PT Remaja Rosdakarya, 1994. Shalahuddin, Mahfud, Psikologi Umum, Surabaya, Bina Ilmu, 1991.

Tasmara, Toto, Kecerdasan Ruhani, Jakarta. Gema Insani, 2001.

Tafsir, Ahmad. Ilmu Pendidikan dalam Perspektif Islam. Bandung. PT Remaja Rosdakarya. 1994.

Unbiyati, Nur. Ilmu Pendidikan Islam I. Bandung. Pustaka Setia. 1998.

Yusanto, Muhammad Islam. Menggagas Pendidikan Islam. Jakarta. Al-Azhar Press. 2004.

Zohar, Danah dan Lan Marshall, $S Q:$ Memanfaatkan Kecerdasan Spiritual dalam Berpikir Integralistik dan Holistik untuk Memaknai Kehidupan, Bandung. Mizan, 2002.

Ulwan, Abdullah Nashih, Pendidikan Anak dalam Islam. Jakarta: Pustaka Amani, cet. III, jilid I\&II, 2002 